\title{
Sustainability or Colonialism? Legislative obstacles to research and development of natural products and patents on traditional knowledge in Brazil
}

\author{
Camilo Tomazini Pedrollo ${ }^{1 \star}$ and Valdely Ferreira Kinupp ${ }^{2}$
}

Received: December 1, 2014. Accepted: May 6, 2015

\begin{abstract}
Historically, developed countries have benefited from the biodiversity and traditional knowledge of developing countries. Since the Convention on Biological Diversity (CBD) was approved, the world-view regarding access to biological resources has changed. This change marked the introduction of legal agreements regarding access to genetic resources, traditional knowledge and benefit sharing, seeking a fair return for owners and local communities. Unfortunately, as with most national laws, these legal devices complicated collection programs and research initiatives, and diminished the emphasis on the discovery of natural products. There remains a lack of discussion on the establishment of a fair international market value for the access to genetic resources. While Brazil still has advantages and opportunities in this arena, the issue sets barriers for research and development. The protective measures are being reviewed in the project bill 7735/2014, which brings improvements, yet it is still controversial. For this short communication we consulted journals, conference proceedings, as well as scientific and journalistic magazines to report some of the disastrous consequences of the implementation of national laws regarding $\mathrm{CBD}$. We suggest a new focus for decision-making policies based on more efficient field inspections, the empowerment of traditional communities and further associated research in order to ensure the claims of $\mathrm{CBD}$ as well as to ratify the Nagoya Protocol.
\end{abstract}

Keywords: community-based conservation, ecosystem management, ethics, human rights, politics and policy

Natural materials of plant, microbial or animal origin are an important potential source of modern drugs. The increasingly high cost involving the discovery of new drugs and molecules by chemical synthesis has forced scientists to look for new resources in natural products (Siaulys 2008). The ability to uncover useful compounds for the development of new products using a small amount of raw material has greatly increased with the development of automated equipment such as HPLC, NMR and MS. It is now possible to conduct a large number of receptor-based trials, chemical characterization and structural determination of compounds (Lewis 2003; Miller 2011). Still, there is no scientific scenario of considerable increase in the number of new discoveries.

Considering the flora issue, where only 60,000 plants are satisfactorily understood chemically, around 2,000 have probably been studied from the stages of plant to drug, of which only 135 have been applied to modern medicine throughout the world (Miller 2011). The numbers demonstrate the importance of continuing research programs, since there are over 240,000 species of plants in the world with potential to provide useful compounds for medicine and other purposes. For this reason it is important to encourage ethnobotanical research before the knowledge of traditional populations is negatively impacted by the processes of rural exodus and loss of biodiversity (Lewis 2003).

Over $80 \%$ of the applied remedies are historically connected to traditional populations. The selection of species based on the assumption of a given therapeutic effect may provide a valuable shortcut to the discovery of new drugs, since its traditional use, as long as it is properly interpreted, can be seen as a pre-trial, suggesting interaction between chemical substances and a biological target (Elisabetsky \& Souza 2004). It is fundamental to consider the elucida-

\footnotetext{
${ }^{1}$ Programa de Pós-Graduação em Botânica, Instituto Nacional de Pesquisas da Amazônia, 69080-971, Manaus, AM, Brazil

${ }^{2}$ Instituto Federal de Educação, Ciência e Tecnologiado Amazonas, Campus Manaus Zona Leste, 69083-000, AM, Brazil

* Corresponding author: camilotp@gmail.com
} 
tion of local notions of diseases to achieve new findings in ethnodirected bioprospecting (Albuquerque et al. 2014).

From an ecological perspective, the discovery of drugs from natural origin provides a strong argument for conservation. Thus, the knowledge of different social groups related to biodiversity has been intensified on the agenda in recent years, especially in the scenario of applied scientific research and related legal regulations. The applied knowledge of traditional populations is not only referenced in drug discovery, but also in various industrial activities, such as biological control, bioremediation, environmental monitoring, civil engineering, mining and industrial materials (Elisabetsky 2005).

One point which demands further attention is understanding how developed countries have benefited and still benefit from traditional knowledge and practices of the indigenous and traditional populations of developing countries (Little 2010). In the 1940's, companies like Wellcome, Lilly and Abbot patented the curare poison used in arrows by Amazonian Indians (Siaulys 2008). Today curare is used worldwide during surgery as a skeletal muscle relaxant to prevent seizures.

Another emblematic example was during the "rubber boom", from 1879 to 1912, when the Amazon Basin experienced important economic development. The Amerindians developed rubber extraction from the rubber tree (Hevea brasiliensis (Willd. ex A. Juss.) Müll.Arg.), a member of the Euphorbiaceae family. The boom resulted in a large expansion of European colonization in the area, attracting immigrant workers, generating wealth and causing cultural and social transformations. The owners of the plantations - rubber barons - made fortunes exploiting those who collected the rubber. The Amazon lost primacy in rubber production as the British Empire planted rubber trees in its colonies in Malaysia, Sri Lanka, and tropical Africa. These trees derived from around 70,000 seeds that Henry Wickham smuggled out from Brazil in 1876 (Ponting 2007), which can be interpreted as one of the most notorious biopiracy events in history. However there was, in fact, no law at the time forbidding their export. Consequently, England took over the control of the world's rubber market due to its lower costs.

It is in the developing countries, with impressive sociobiodiversity, principally in the tropics, that people have served as holders of natural resources for centuries. The Convention on Biological Diversity (CBD) was signed at the United Nations Conference on Environment and Development (ECO-92) in Rio de Janeiro in June 1992 (MMA 2000). Consequently, the worldview on access to biological resources has changed. The CBD was a commitment of signatory countries to protect biological diversity, to use it sustainably and to share the benefits equitably, guaranteeing the right of states to explore their own resources, recognizing national sovereignty over their own biodiversity (Lewis 2003; Moreira 2005; Magalhães 2006; Lemos 2008).
More than 190 countries worldwide have made the important decision of ratifying CBD. In 2010, another important conference was taken in Nagoya, deciding that countries which explored the biodiversity of others, even before the $\mathrm{CBD}$, should compensate the countries from which the appeal was taken (MMA 2011). Even so it still cannot ensure satisfactory preservation, appreciation and valuation of the much discussed socio-biodiversity (Diegues 2000). Here, we report some disastrous consequences of the implementation of national laws regarding CBD in Brazil as well as other examples from Latin American countries.

After the official acceptance of the CBD, a partnership was created between the U.S. Agency for International Development (USAID) and the Forgatry International Center of the National Institutes of Health (NIH), thereby creating the International Cooperative Biodiversity Groups Program (ICBG). The proposal was to discover and develop drugs and other useful agents from natural products in developing countries, promoting sustainable economic growth while preserving the biological resources from which these products were extracted (Lewis 2003; Berlin \& Berlin 2004; Rosenthal et al. 1999).

In the case of the Maya ICBG-Chiapas, Mexico, the project had a major component for technology transfer, which was committed to reversing the current paradigm that developing countries should send raw materials to developed countries for scanning and running pharmacological tests (Berlin \& Berlin 2004). The project failed due to a NGO's representation which withdrew the autonomy of communities that had agreed to participate in an international partnership for the discovery of new drugs. The ICBG-Peru is one of the most successful initiatives because it created strong cooperative links with indigenous communities which were divided into four well-organized federations. They were represented by another umbrella organization which was able to offer institutional stability.

In Brazil, Senator Marina Silva presented a project bill (projeto de lei do senado $\mathrm{n}^{\circ}$ 306, de 1995 - not published) aiming at the implementation of the CBD. Nowadays the regulations currently in effect focus on the application of the rules established by Provisional Measure 2186 (Brasil 2001) and numerous technical guides, regulatory instructions and resolutions which determine guidelines for access to traditional knowledge (Tab. 1). The Genetic Patrimony Board of Management (Conselho de Gestão do Patrimônio Genético CGEN) was chosen as the authority to assess these projects (Azevedo 2005; Machado \& Godinho 2012). Although seemingly well intentioned, these measures have gradually distorted the original intent of the $\mathrm{CBD}$ as they are based on excessive bureaucratic requirements and coercion (Clement 2007).

Since the establishment of the Provisional Measure, the system has become increasingly complicated, largely due to the tendency toward excessive profit expectations (Clement 2007). For Rosenthal et al. (1999), drug discovery is a high risk science, because only a small part of the scientific 
Table 1. Some Brazilian orientations and resolutions after the Provisional Measure 2186 with brief synthesis of decisions.

\begin{tabular}{|c|c|}
\hline Legal Parameter & Decisions \\
\hline Decree 3945/2001 & Define Board of Management of Genetic Patrimony (CGEN) as the authority to assess projects \\
\hline Technical Orientation 01/2003 & Define the concept of access and genetic patrimony \\
\hline Draft bill $(A P L) / 2003$ & Aimed to replace the MP but it was not sanctioned \\
\hline Resolution 21/2006 & Phylogenetic studies that do not fall within the concept of access to genetic patrimony \\
\hline Resolution 29/2007 & $\begin{array}{l}\text { Homemade extracts and fixed oils that do not fall within the concept of access to genetic patrimony - aims to } \\
\text { protect traditional communities }\end{array}$ \\
\hline Resolution 279/2011 & $\begin{array}{l}\text { Attaches to other organizations specific authorization to public or private national institutions, engaged in } \\
\text { research activities, development and innovation }\end{array}$ \\
\hline Project bill 7735/2014 (not sanctioned) & $\begin{array}{l}\text { Regulates the access to genetic resources, the protection and access to associated traditional knowledge and the } \\
\text { sharing of benefits for conservation and sustainable use of biodiversity; repeals the Provisional Measure } 2186\end{array}$ \\
\hline
\end{tabular}

investment will turn into products to be commercialized and therefore become profitable. Thus, a well-designed bioprospecting mechanism should focus on achieving the three main goals currently being discussed: health, economic development and sustainability or conservation of biodiversity, rather than promises of high profit.

A recent yet emblematic case is the project named "Network of chemical compounds research for the control of malaria with an ethnopharmacological approach in the states of Amazonas and Acre", approved and funded by "National Council of Technological and Scientific Development", $\mathrm{CNPq}$ ), under the coordination of Dr. Lin Chau Ming (UNESP-Botucatu). According to a recent release (MMA 2012), UNESP sent documentation for approval and 22 months later the claim stated that 'the documentation did not meet the provisions of CGEN resolutions', because it showed irregularities in prior concessions collected in 55 communities in various regions of the Amazon. Despite having received official financial support from a federal organization, the project still encountered bureaucratic obstacles (Tomchinsky et al. 2013).

This type of delay by a regulatory body can ruin a research project, which often deals with short deadlines in accounts and results deliver. There is an immense lack of prior clarification by the competent bodies in order to stimulate research and hence the proper collection of documentation. This makes basic research permission very hard to obtain. Academic research of short duration often faces illegality in Brazil, as in the case of masters dissertations and doctoral theses. Current legislation requires numerous terms of agreements, and it takes months or even years for a verdict to be issued. Many projects are ultimately discouraged to adopt ethnological approaches involving traditional knowledge.

Many legislative changes were taken in order to reduce bureaucracy. In 2011 the National Institute of Historical and Artistic Heritage (IPHAN) was registered as the entity in charge of applications from national, public or private institutions engaged in research and development activities to access traditional knowledge for scientific research purposes, with no access to genetic resources (Brasil 2011). The $\mathrm{CNPq}$ and the Brazilian Institute of Environment and
Renewable Natural Resources (IBAMA) were also registered for other purposes, accelerating some process.

Only by the end of 2014 was Project Bill 7735 brought to the Senate by the National Congress with the aim of facilitating access and benefit sharing from the use of common natural resources and traditional knowledge for product development and scientific experiments, thereby repealing the Provisional Measure 2186 (Brasil 2014). Up until this paper was published, the Project Bill was criticized by social movements and organizations because it prevents people and traditional communities from controlling access to their knowledge. While on one hand it ensures access of industries and researches to genetic resources and traditional knowledge, on the other hand it faces lack of guarantee to the needs of the holders of traditional knowledge.

There are still other gaps in the Brazilian legislation that negatively affect the development of projects. Many forms of traditional use of plants are shared among several communities. Knowledge is therefore not concentrated but spread amongst a wide network. One example is the use of oil extracted from the seeds of andiroba (Carapa guianensis Aubl. - Meliaceae), which is widely used throughout the Amazon for wounds and other purposes. Understanding the distribution of benefits in these cases is very complex, so simply permitting any local community or family member to participate in a research study would be inaccurate. Similarly, legislation does not address second-generation knowledge, which is understood as the knowledge passed to people not belonging to traditional communities but with the potential to reproduce it to different contexts.

Therefore, it behooves us to ponder the following: are the current technical guidelines sustainably protecting the biodiversity, or are they contributing further to its neglect, just as in colonial times? According to Clement (2007), protection logic has been reversed and now proves detrimental to any advance regarding Brazilian biodiversity. It is worth noting that potential biopirates probably show very little attention in solving the bureaucratic procedures of access law in Brazil. Tomchinsky et al. (2013) points that Malaysia is currently developing another natural products value chains such as Brazilian nuts, pirarucu and ornamental fishes, following the same steps of the rubber tree case long ago. The 
airport surveillance service of the IBAMA acknowledged that the fight against biopiracy and wildlife trafficking is insufficient. IBAMA is responsible for the protection of the flora and fauna of the country but the Court of Auditors (TCU) report concluded that the agency's monitoring work at airports and borders is poor (Pimentel 2006). In the official website of IBAMA, in the section called "special actions of inspection in the genetic heritage arena", all you can see is a blank page, devoided of content (IBAMA 2015).

The only groups challenging the bureaucratic barriers against biopiracy are research, development and innovation (RDI) sectors from national institutions, and therein lies the decrease in interest when it comes to maintaining working relationships with traditional communities, increasing their potential instead of depriving them of developmental processes. Ever since the Brazilian government enacted the Provisional Measure, the annual number of patent applications of biotechnology in Brazil plummeted by nearly $70 \%$, from 1,030 deposits in 2001 to 356 in 2010 (Adeodato 2011). The drop in patent applications is worrying, given the current scenario of risks and uncertainties. As stated in the CBD, countries should develop national legislation on access, yet it is difficult to establish a fair international market value for access to genetic resources. As a result, each country has its own laws and each law has slow negotiation processes, complicating international research agreements. Such disparities in the laws of different countries creates barriers and conflicts.

Brazil has key advantages and opportunities for development in the arena of medicinal plants and herbal medicines. It is a country with mega-diverse plant species, great social diversity, strong traditions of medicinal plant usage and it has developed the technology for scientific and technological research in this field (Vasconcellos 2005; Barbano 2008). Furthermore, the low cost of raw material can be linked with good conditions for local clinical studies and thereby begin to encourage national pharmaceutical companies to seek a new direction in the development of herbal medicine.

In 2004 the National Bank of Development (Banco Nacional de Desenvolvimento- BNDES) created a program called National Policy on Medicinal Plants and Herbal Medicines (Política Nacional de Plantas Medicinais e Fitoterápicos), coordinated by the Health Ministery (Barbano 2008; Torres 2008). It is not just about generating income for the national pharmaceutical industry, but rather about setting Brazil into a prominent position in general, following a global strategy established by the World Health Organization $(2002 / 2005$ plan) with regard to traditional medicine (Siaulys 2008). The strategy includes secure access and rational use of medicinal plants, while also promoting the development of the productive chain and national industry (Barbano 2008; Torres 2008). Despite this promising scenario, there is still a lot to be done since domestic pharmaceutical industry is almost entirely dependent on products and raw material produced by rich countries (Calixto 2008). For universities, product development requires patent protection of their inventions and that has not yet been adequately valued in the Brazilian academy (Barata 2008).

The result of the CBD application in Brazil has largely been manifested through barriers to research and development, which are often viewed as basic elements in the preservation of natural resources (Oliveira et al. 2009). Within this context, Ethnobotany is currently experiencing some uncertainty regarding the fate of research depending on access to traditional knowledge associated to genetic diversity (Oliveira et al. 2009). It is necessary to protect traditional knowledge and genetic resources without impeding the development of national research involving access to these elements. According to Braulio Dias, former aide to Environment Ministery and current Executive Secretary of the CBD, Brazil has sought to reverse this situation unsuccessfully. National legislation should not only solve the problem of biopiracy but should also support the Nagoya Protocol, ensuring international protection of the biological heritage of every country (Dias 2013).

Today, Brazil still has not achieved national autonomy to manage socio-biodiversity as is also the case in many Latin American countries. This implies a certain detachment from sustainability policies, with an exploiting model prevailing as to the treatment of local communities and traditional knowledge. We may notice that excess of legislation now in practice restrains the development of national RDI and patents in natural products. This excess is creating disastrous consequences, including the following:

1) The barriers in Brazilian law results in delays, fines and often the failed execution of a great amount of national research;

2) Indigenous and traditional populations remain marginalized in the majority of the vast national territory. Despite good opportunities, there is a lack of projects aiming at local development;

3) With lack of research in local communities, people are faced with lack of appropriate welfarism and information, which can contribute to the establishment of bad management practices, unregulated trade operations of raw material and natural products as well as misappropriation of associated traditional knowledge;

4) Bureaucratic obstacles have stalled efforts to increase the power and capacity of field inspection bodies, such as IBAMA, which have ceased to be prioritized.

Brazil will only achieve satisfactory human development if it consistently invests, plans and trains qualified personnel in the rational use of natural resources. It is necessary to protect traditional knowledge which, according to UNESCO, is part of humanity's cultural heritage, by encouraging the development of national research, including access to the elements of biodiversity and consequently empowering local communities. The presence of research initiatives is essential to do so.

These impasses are far from being resolved and constitute real obstacles to research and development of products 
and patents on traditional knowledge throughout Latin America, Brazil and especially the Amazon.

\section{Acknowledgments}

The authors thank Charles Clement, Michael John Gilbert Hopkins, Glenn Shepard Jr. and Lin Chau Ming for their large contributions in lengthy discussions on the subject. We would also like to thank the riparian people at Jauaperi river, where the first author conducted his master's research and where many of the insights brought here emerged. We thank CAPES, the sponsors and the anonimous referees for the contributions.

\section{References}

Adeodato S. 2011. Impasse na floresta. Valor Econômico. http://www. valor.com.br/impresso/ambiente/impasse-na-floresta. 21 May 2012.

Albuquerque UP, Medeiros PM, Ramos MA, et al. 2014. Are ethnopharmacological surveys useful for the Discovery and development of drugs from medicinal plants? Brazilian Journal of Pharmacognosy 24: 110-115.

Azevedo CMA. 2005. A regulamentação do acesso aos recursos genéticos e aos conhecimentos tradicionais associados no Brasil. Biota Neotropica 5: 1-9.

Barata LES. 2008. Oportunidades em fitomedicamentos no Brasil. São Paulo, XX Simpósio de Plantas Medicinais do Brasil/ X International Congress of Ethnopharmacology.

Barbano D. 2008. Programas da Secretaria de Ciência e Tecnologia para desenvolvimento de fitomedicamentos. São Paulo, XX Simpósio de Plantas Medicinais do Brasil/ X International Congress of Ethnopharmacology.

Berlin B, Berlin EA. 2004. Community autonomy and the Maya ICBG Project in Chiapas, Mexico: how a bioprospecting project that should have been succeeded failed. Human Organization 63: 472-486.

Brasil. 2001. Medida Provisória n 2.186-16, de 23 de Agosto de 2001. Diário Oficial da União, Seção 1 - Eletrônico - 24/8/2001, Página 11 (Original publication).

Brasil. 2011. Deliberação 279, de 20 de setembro de 2011. http://portal. saude.gov.br/portal/arquivos/pdf/autorizacaoMPMS479.pdf, 30 Aug. 2012. Diário Oficial da União - DOU, 2011.

Brasil. 2014. Projeto de Lei da Câmara (PLC) 7735-D de 2014. http:// www.camara.gov.br/proposicoesWeb/fichadetramitacao?idProposi$\mathrm{cao}=619150.5$ May 2015 .

Calixto JB. 2008. O desenvolvimento de medicamentos no Brasil e a necessária interação entre universidades e indústrias farmacêuticas. São Paulo, XX Simpósio de Plantas Medicinais do Brasil/ X International Congress of Ethnopharmacology.

Clement CR. 2007. Um pote de ouro no fim do arco-íris? O valor da biodiversidade e do conhecimento tradicional associado, e as mazelas da lei de acesso - uma visão e proposta a partir da Amazônia. Amazônia: Ciência e Desenvolvimento 3:7-28.

Dias B. 2013. Secretário executivo da Convenção sobre Diversidade Biológica fala sobre responsabilidade na preservação ambiental. Revista Veja 46(5): 13-15.

Diegues AC. 2000. Etnoconservação: novos rumos para a proteção da natureza nos trópicos. São Paulo, Hucitec.

Elisabetsky E. 2005. Saber tradicional e repartição de benefícios: por quê? In: Ming LC, Carvalho I, Vasconcellos MC, Radomski MI, Costa MAG. (eds.) Direitos de recursos tradicionais: formas de proteção e repartição de benefícios. Botucatu, SBEE - UNESP. p. 47-54.

Elisabetsky E, Souza GC. 2004. Etnofarmacologia como ferramenta na busca de substâncias ativas. In: Simões CNO, Schenkel EP, Gosmann G, Mello JCP, Mentz LA, Petrovick PR. (eds.) Farmacognosia: da planta ao medicamento. 5th edn. Porto Alegre/Florianópolis, Editora da UFSC/Editora da UFRGS. p. 107-122.

IBAMA - Instituto Brasileiro do Meio Ambiente e dos Recursos Naturais Renováveis. 2015. Ações Especiais de Fiscalização na Área de Acesso ao Patrimônio Genético - Biopirataria. http://www.ibama.gov.br/ fiscalizacao/biopirataria. 22 Apr. 2015.

Lemos C. 2008. A repartição de benefícios segundo a legislação brasileira. São Paulo, XX Simpósio de Plantas Medicinais do Brasil/ X International Congress of Ethnopharmacology.

Lewis WH. 2003.Pharmaceutical discoveries based on Ethnomedicinal plants: 1985 to 2000 and beyond. Economic Botany 57: 126-134.

Little PE. 2010. Os conhecimentos tradicionais no marco da intercientificidade. In: Little PE. (ed.) Conhecimentos Tradicionais para o Século XXI - etnografias da intercientificidade. São Paulo, Annablume. p. 09-31.

Machado CS, Godinho RS. 2012. Acesso ao patrimônio genético e conhecimentos tradicionais. Revista da Sociedade Brasileira para o Progresso da Ciência - Psicanálise e linguagem mítica 64: 4-5.

Magalhães VG. 2006. A Convenção sobre Diversidade Biológica (CDB): a necessidade da revisão do seu texto substituindo o termo "Recursos Genéticos" por "Recursos Biológicos" nos arts 1, 9, 15, 16 e 19. Revista Eletrônica do Curso de Direito da UFSM1: 16-32.

Miller JS. 2011. The discovery of medicines from plants: a current biological perspective. Economic Botany 65: 396-407.

MMA - Ministério do Meio Ambiente. 2000. A Convenção sobre Diversidade Biológica. Brasília, Programa Nacional de Conservação da Biodiversidade.

MMA - Ministério do Meio Ambiente. 2011. Quarto relatório nacional para a convenção sobre diversidade biológica. Brasília, DF.

MMA - Ministério do Meio Ambiente. 2012. Ofício no 129/2012/DPG/ SBF/MMA. Brasília - DF

Moreira TC. 2005. O acesso ao patrimônio genético e aos conhecimentos tradicionais associados e os direitos de comunidades indígenas e locais no Brasil. In: Ming LC, Carvalho I, Vasconcellos MC, Radomski MI, Costa MAG. (eds.) Direitos de recursos tradicionais: formas de proteção e repartição de benefícios. Botucatu, SBEE - UNESP.p. 55-86.

Oliveira FC, Albuquerque UP, Fonseca-Kruel VS, Hanazaki N. 2009. Avanços nas pesquisas etnobotânicas no Brasil. Acta Botanica Brasilica 23: 590-605.

Pimentel C. 2006. Coordenador do Ibama reconhece fiscalização deficiente contra biopirataria. Agência Brasil. http://noticias.ambientebrasil. com.br/clipping/2006/09/18/26854-coordenador-do-ibama-reconhece-fiscalizacao-deficiente-contra-biopirataria.html. 22 Apr. 2015.

Ponting C. 2007. A New Green History of the World: The Environment and the Collapse of Great Civilizations. New York, Penguin Books.

Rosenthal JP, Beck D, Bhat A, et al. 1999. Combining high risk science with ambitious social and economic goals. Pharmaceutical Biology 37: 6-21.

Siaulys V. 2008. Fitomedicamentos: vocação natural da indústria farmacêutica nacional. São Paulo, XX Simpósio de Plantas Medicinais do Brasil/ X International Congress of Ethnopharmacology.

Tomchinsky B, Ming LC, Hidalgo AF, Carvalho I, Kffuri CW 2013. Impactos da legislação na pesquisa etnobotânica no Brasil, com ênfase na Região Amazônica. Amazônia, Revista de Antropologia (Online) 5: 734-761.

Torres K. 2008. O Ministério da Saúde como promotor da validação de fitoterápicos - a PNMF e a validação clínica, planejamento e financiamento. São Paulo, XX Simpósio de Plantas Medicinais do Brasil/ $\mathrm{X}$ International Congress of Ethnopharmacology.

Vasconcellos AG. 2005. Propriedade intelectual dos conhecimentos associados ao estudo das plantas medicinais: desafio para a gestão autônoma da biodiversidade brasileira. In: Ming LC, Carvalho I, Vasconcellos MC, Radomski MI, Costa MAG. (eds.) 2005. Direitos de recursos tradicionais: formas de proteção e repartição de benefícios. Botucatu, SBEE - UNESP. p. 21-46. 